\title{
Etiese prediking in post-apartheid Suid-Afrika? Enkele homiletiese oorwegings
}

\author{
Shaun Burrows \\ Universiteit Stellenbosch, Suid-Afrika \\ shaunvb007@gmail.com \\ Johan Cilliers \\ Universiteit Stellenbosch, Suid-Afrika \\ jcilliers@sun.ac.za
}

\begin{abstract}
Ethical preaching in post-apartheid South Africa? A few homiletic considerations

This article will try to indicate that while the church's approach during the apartheid era was characterized by liberation theology and preaching, the post-apartheid era that is still characterized by social decay, moral impoverishment and especially an increase in poverty, family violence, divorce and a spirit of individualism - asks for an increased focus on sustainable poverty eradication. It is argued that in post-apartheid South Africa a fundamental consensus on binding values, non-negotiable standards and morally acceptable ground attitudes are urgently needed. It is in this context that the role of ethical preaching is examined. In a context of widespread poverty, unemployment and a sense of insecurity, apathy, unconcern and depression among many ethical preaching, as an orientation event, can bring a new dignity to people.
\end{abstract}

Key words

Ethics; preaching; poverty; post-apartheid

\section{Agtergrond}

Bevrydingsteologie het primêr gehandel oor die bevryding van die sosiaal-politiese en ekonomiese verdruktes. Die leiers van die gemeenskap of land spreek en handel in hierdie teologie oor geregtigheid vir hul mense (Mugambi 2003:28, 165). Volgens swart Christene is in dié tyd van verdrukking in Suid-Afrika gesoek na 'n woord wat vertel het van God se nabyheid in hul lewens, 'n woord wat 'n weg gewys het uit die 
stikke duisternis van verdrukking, armoede en ellende, en terselfdertyd aangespoor het tot aktiewe deelname aan God se stryd vir geregtigheid en bevryding (Boesak 1979:2).

Terwyl die kerk se benadering tydens die apartheidsera gekenmerk is deur bevrydingsteologie en -prediking, vra die post-apartheid era, wat steeds gekenmerk word deur sosio-maatskaplike verval, morele verarming en veral toename in armoede, gesinsgeweld, egskeidings en 'n gees van individualisme, 'n verskerpte fokus op die volhoubare uitwissing van armoede. Die hoeveelheid mense wat, volgens Statistieke Suid-Afrika (2017) van die Suid Afrikaanse bevolking in armoede leef, het afgeneem vanaf 66,6\% (31,6 miljoen mense) in 2006 tot 53,2\% (27,3 miljoen) in 2011. Dit het egter verhoog tot 55,5\% (30,4 miljoen) in 2015. Die hoeveelheid mense wat in absolute armoede leef, dit wil sê onder die 2015 broodlyn van R441 per persoon per maand, het verhoog met 2,8 miljoen vanaf 11 miljoen in 2011 tot 13,8 miljoen in 2015. Die werkloosheidsyfer volgens Gous (2017) onder mense wat in armoede woon, het amper verdubbel tot $27,7 \%$ in die derde kwartaal van 2017, terwyl die werkloosheidsyfer onder die jeug gegroei het tot $38,6 \% .{ }^{1}$ Armoede kan op baie maniere gedefinieer word. Die mees gebruiklike definisie handel oor gebrek aan basiese lewensmiddels, 'n uitsluiting van ekonomiese en sosiale infrastrukture en 'n vervreemding van die res van die gemeenskap. ${ }^{2}$ Slegs ongeveer die helfte van die bevolking van Suid-Afrika kan as "nie-arm” geklassifiseer word.

Terwyl die Christelik-etiese refleksie onder apartheid gekenmerk is deur 'n modus van weerstand - gemik daarop om die mure van apartheid af te breek - moet die kerk in die post-apartheid era na 'n modus van samewerking skuif om die mure van die sosiale infrastruktuur wat deur die armes en gemarginaliseerdes benodig word, op te bou. Vanselfsprekend kan dieselfde gereedskap wat gebruik is om die mure af te breek nie dieselfde kan wees waarmee dit weer opgebou word nie. Tog is die prediking die een essensiële aspek in die apartheidsera wat gebruik is om die mure van apartheid af te

1 Gous N. 2017: SA most unequal country in world: Poverty shows Apartheid's enduring legacy. Times Live, 4 April 2018. [Online]. Available: https://www.timeslive.co.za/news/southafrica/2018-04-04-poverty-shows-how-apartheid-legacy-endures-in-south-africa/

2 Wanneer daar nie genoeg kos is om die familie of jouself te voed nie, leef mense voort in armoede. Daar is te veel inwoners in 'n klein vertrek of huisie. Daar is 'n gebrek aan skoon water en basiese vorms van energie, asook'n gebrek aan werksgeleenthede. 
breek en is dit ook, na my mening, een van die gereedskapstukke om te help om armoede en ongeregtigheid aan te spreek.

Uit die voorafgaande is dit duidelik dat die kerk 'n unieke rol het om te vervul in die herstel of ontwikkeling van gemeenskappe, oftewel gemeenskapsontwikkeling. ${ }^{3}$

Indien ons God se liefde, genade, heil en bevryding aan die armes in ons land wil kommunikeer, sal ons dit met konkrete dade van opheffing moet doen. Die kerk word opgeroep om met daad en woord, waarskynlik in hierdie volgorde, onder die armes op te tree, gedring deur die Christelike liefde. Hierdie volgorde sou goedskiks ook omgeruil kon word: ons moet eerstens die Woord verkondig sodat mense deur die Woord verander kan word deur die werking van die Gees (Pieterse 2001:118).

\section{Waarom etiese prediking?}

Wat post-apartheid Suid-Afrika dringend benodig, is 'n fundamentele konsensus aangaande bindende waardes, ononderhandelbare standaarde en moreel aanvaarbare grondhoudings teenoor mekaar. Dit is juis in hierdie verband dat die rol van die prediking ter sprake kom. Die kerk kan 'n fasiliteerder en begeleier word in die vraagstukke oor armoede en ontwikkeling. Binne hierdie proses kan etiese prediking 'n integrale rol vervul, aangesien etiese prediking, as uitdrukking van 'n eties verantwoordelike religie, by uitstek gerig is op die verandering van waardes en grondhoudings (Swart 2004b:490).

Etiese prediking is daarop gerig om die verstand, gemoed en wil van die hoorders aan te spreek. Dit wil informasie verskaf (die verstand aanspreek), die hoorders emosioneel aanraak (die gemoed aanspreek), maar uiteindelik ook tot handeling beweeg (die wil aanspreek) (Pieterse 2001:28). Hierdie etiese prediking as oriëntasiegebeurtenis neem in die eerste plek die konteks uiters ernstig op, in dié sin dat die konteks (van armoede, ens.) die prediking voortdurend inhoudelik en formeel informeer.

3 "Die primêre doel van gemeenskapsontwikkeling is om mense wat in absolute armoede leef daaruit te bevry" (Hendriks 1998:38). 
Etiese prediking as oriëntasiegebeurtenis gaan egter ook verder, deurdat dit alternatiewe moontlikhede en nuwe wêrelde voorhou. Die (etiese) prediking van die evangelie help mense deur hulle altyd te verras met nuwe vreugde, altyd te verstom met nuwe hoop, terwyl hulle gedink het daar bestaan nie meer so iets nie. Dit hou metafore van 'n nuwe samelewing voor, wat bestaandes dekonstrueer en disoriënteer, ten einde reoriëntasie te bewerkstelling (Cilliers 2000:13, 49, 119). In die etiese prediking word uiteindelik'n nuwe visie van dié soort samelewing wat God vir sy mense en skepping in die oog het, aan die hoorders voorgehou.

\section{Die doel van etiese prediking}

Ons moet maniere vind om die bestaande oorsake van armoede te konfronteer. Ons kan nie net bekommerd wees oor die effek van armoede en ongeregtigheid nie, ons moet die sisteme aanspreek wat hierdie ongeregtigheid veroorsaak (Hauerwas 1977:132-134).

Die Christelike lewe is meer as net om te identifiseer met die verdruktes of om 'n verdrukte te wees. Die huidige toestand van die kerk onder andere is toe te skryf aan die verskynsel van sogenaamde etikettering. Daar is die etikettering van groepe en individue, wat dan juis struikelblokke word waarna mense luister en waardeur hulle hul menings laat vorm. Dit kan lidmate so besig hou en soveel aandag vereis, dat dit veroorsaak dat lidmate nie mekaar sien vir wie hul werklik is nie. Dit verhoed ook dat mense mekaar se waardigheid genoeg respekteer om net na daardie persoon te luister, om werklik aandag te gee aan hul gevoelens en geloofwaardigheid, in plaas daarvan om net te reageer volgens die etiket wat aan daardie mens toegedig is. Christene word erken deur 'n opregte respek vir die waardigheid van ander, ongeag hul omstandighede (Crossin 1998:40).

Die erkenning van persoonlike feilbaarheid is dus wesenlik as teenvoeter vir etikettering. Hierdie erkenning maak mense meer oop om meer te leer. Daar is veronderstel om 'n wedersydse respek vir die waardigheid van ander by arm mense, sowel as by ryk mense binne die kerk te bestaan. Die vraag na ons emosies, rede en dade is tegelykertyd 'n vraag na die vernuwing van ons morele lewe. Om dit nog verder te voer: die morele vernuwing van arm en ryk lê in die uitdaging tot teologies verantwoorde etiese prediking (Crossin 1998:41-44). 
Ons prediking, met alle etiese dimensies daarvan, is 'n voortsetting van die prediking van Jesus Christus. In ons prediking gaan die opgestane Christus voort om met die kerk te praat en deur die kerk tot die wêreld. Deur ons prediking word Christus aan die wêreld bekend gestel. Die doel van prediking is die doel van God in Christus, naamlik versoening met die wêreld. Ons prediking as 'n voortsetting van Christus se prediking en werk is nie net gemik op 'n hartsverandering nie, maar sodat ons inderdaad anders as die wêreld kan wees. Die reaksie wat prediking moet ontlok, is 'n wegbeweeg van die ou weë en manier van dink na 'n nuwe manier van handel (Buttrick 1987:449-457).

Cilliers sluit hierby aan en beskryf prediking as:

Preaching communicates more than mere information about God to others; it is the performance of God's voice through historical distances, the mists of incomprehension and deafness of ears ... A sermon is much more than the transfer of religious information, also much more than mere words on written manuscript. It rather is a word event and a Word event, the sound of a voice, non-recurrent and unique. (Cilliers 2013:2)

Die doel van prediking is dus om die werk van Christus voort te sit in die wêreld met die belofte van die teenwoordigheid van die Heilige Gees en die oortuiging dat daar daadwerklik iets met die luisteraar gebeur. 'n Goeie preek spruit voort uit 'n huwelik tussen die Bybelse teks en die menslike gedragsdoel. 'n Verandering in gedrag is die doel van spirituele groei. Die integriteit van die teks is primêr, maar die prediker moet weet hoe hy of sy die hoorder op 'n ander manier wil laat optree nadat hulle die preek gehoor het (Mitchell 1990:51).

Die luisteraar word daadwerklik, ontologies, getransformeer. Of, in die woorde van Feltman: “... the end to be desired in preaching is not hearing, but changed behaviour ...” (1996:13).

Die verdere doel van prediking is om 'n ontmoeting tussen God en mens tot stand te bring. Binne hierdie kommunikatiewe konteks waarin God by ons en ons by Hom is, kan daar kontak en kommunikasie met God wees. Wanneer mense die boodskap uit die Bybel hoor, waarin God se wil en sy roeping in sy woorde en dade bekend word deur die ervaring en getuienisse van die mense van die Bybelse tyd heen, dan kan mense 'n ervaring van 
God hê. So 'n ontmoeting bring verlossing, heil, 'n nuwe lewe, nuwe hoop en inspirasie. Mense sien dan die lewe gewoonlik in 'n ander lig en 'n nuwe perspektief - dit is die vrug van etiese prediking (Pieterse 2001:18).

Ons bely dat dit alles alleen moontlik is deur die werk van die Heilige Gees. Hierdie werk van die Gees word moeilik waargeneem of vasgepen. Dit is soos die wind wat waai sonder dat jy die wind kan sien. Maar jy hoor sy geluid en jy sien en beleef sy effek. Mense wat glo in God en hul lewe aan Hom toewy, word in die geloof deur die bediening van die kerk opgebou, waarby die prediking ook 'n belangrike rol speel. Dit is die soort mense wat deur die Christelike geloof gevorm word en wat in ons konteks die stryd teen hul omstandighede kan aanpak om hul lot te verbeter. Om die vraag aangaande die doel van prediking dus te antwoord is eerstens om te erken dat prediking verandering kan bring - daar waar die prediker die goeie nuus van God se bevrydende en versoenende werk verkondig.

Die vraag is egter, wat is dan hierdie Goeie Nuus? En, om te vra wat is die goeie nuus beteken ook om te vra: Watter preke is goeie nuus?

\subsection{Etiese prediking as profetiese prediking}

Profetiese prediking is die verkondiging van God se wil vir God se mense in die konteks van hul gemeenskap en die wêreld. Dit beteken egter nie dat profetiese prediking sy boodskap ontwikkel en vanuit 'n psigoterapeutiese perspektief verkondig, of dat dit 'n sosiale program voorstel vanuit die perspektief van publieke welsyn, of dat dit saamwerk met nasionale regerings of sekulêre organisasies om die publieke behoeftes te dien nie. Profetiese prediking is ook nie 'n skoling wat mense wil oorreed om 'n sekere ideologie of 'n sekere sosiale of politieke siening of program aan te neem nie. Profetiese prediking wil egter die gemeente inlig aangaande God se wil sodat die verhouding tussen God en sy mense herstel kan word. Dit beoog om God se wil en intensie vir sy mense, die gemeenskap, die hele mensdom en die wêreld bekend te maak, asook die implikasies daarvan vir sosiale en politieke realiteite in geheel.

In short, prophetic preaching should be a passageway through which God's will is proclaimed and realized in relation to the needs of God's people, to social issues, and political situations (Kim 1999:136). 
Predikers is seuns en dogters van dié profete wat 'n duidelike profetiese bediening moet hê. Daar is egter verskeie vereistes wat benodig word vir 'n profetiese bediening. Die primêre vereiste is dat predikers sal besef dat hulle geroep is om onder outoriteit te werk en leef. Deelname in profetiese prediking is nie primêr net 'n werk of kontrak nie. Dit is nie iets waarvoor predikers gehuur of uitgenooi word om te doen nie, maar die woorde en gedagtes wat gepreek word, kom van God, onder wie se outoriteit predikers staan.

Hierdie eerste aspek van profetiese prediking en bediening is kritiek. In 'n bloeiende, self-tevrede en selfbekragtigde samelewing is dit die opdrag van predikers as seuns en dogters van profete om die mag van God se woord te bring in die vorm van kritiek teen alle vorms van selfbelang wat die swakkes en die magteloses afskeep. Dit is tydens sulke prediking dat lidmate, maar ook die magte en strukture van die samelewing daaraan herinner moet word dat hulle nie onpartydig kan wees teenoor die verwrongenheid van menslike lewe en die menslike gemeenskap nie. Die profetiese kritiek in prediking vra vir 'n duidelike verstaan van wat God vra van die menslike gemeenskap. Hierdie kritiek is ook teen almal wat nie geregtigheid en regverdigheid as primêre kriteria gebruik in hul benaderings tot die samelewing nie (Miller 2003:77).

In profetiese prediking word die kerk se situasie en behoeftes, sosiale konteks en kontemporêre uitdagings, asook die kerk se verantwoordelikheid ten opsigte van die gemeenskap, soos dit die hoorders asook die gemeenskap raak, aan die orde gestel en verkondig. Profetiese prediking is egter nie net die teenswoordige verkondiging nie, maar is ook eskatologies van aard. Dit beteken dat profetiese prediking dui op die voorlopigheid van alles, maar ook op die realiteit van God se beloftes, hier en nou; dat die "alreeds" en "nog nie" verkondig word. In die proses kan die boodskap van oordeel ook nie geïgnoreer word nie. Profetiese prediking spreek die sondes van God se mense en die korrupsie en ongeregtigheid in die gemeenskap aan. Dit is veronderstel om gedoen te word met direktheid en passie, maar nie met woede of haat nie (Kim 1999:150).

'n Verdere voorwaarde vir profetiese prediking is solidariteit met die armes. In 'n kontemporêre konteks van armoede word die kerk in die breë uitgedaag as dissipels van Jesus Christus om te staan aan die kant van die 
armes. Dit is onmoontlik om die armes in Suid-Afrika te ignoreer en om net te preek oor geloof as 'n private en spirituele saak. Hierin is dit duidelik dat die ongeregtigheid en onregverdigheid in die samelewing aangespreek moet word deur profetiese prediking.

The principalities and powers are the inner and outer aspects of any given manifestation of power. As the inner aspect they are the spirituality of institutions, the within of corporate structures and systems, the inner essence of outer organizations of power. As the outer aspect they are political systems, appointed officials, the chair of an organization, laws- in short, all the tangible manifestations which power takes. Every Power tends to have a visible pole, and an invisible pole, an inner spirit or driving force that animates, legitimates, and regulates its physical manifestation in the world (Campbell 2002:20)

Wat dus nodig is, is nie net dat daar vir mense in armoede gepreek word nie, maar dat die magte wat bydra tot die groei in armoede aangespreek word. Hiervoor word die stem van die ekumeniese kerk benodig. In 'n konteks van ongeregtigheid en uitsluiting reik profetiese prediking oor die grense van 'n enkele gemeente Dit het 'n boodskap vir die ekumeniese Christelike kerk, die breër samelewing en die regering (Pieterse 2013:8).

\subsection{Etiese prediking handel oor geregtigheid}

Die evangelie van Jesus Christus bly die fondament waarop die prediking gebou is. Wanneer Christene nie net die siekes besoek en die lydendes vertroos nie, maar ook probeer om honger te bekamp en om gesondheidsorg vir almal te bewerk, is dit hul getuienisse van die gesondheid en heelheid van God se finale toekoms in Jesus Christus. Wanneer Christene met die armes identifiseer en alle vorms van verdrukking teenstaan, verwag hulle die vrede van God se regering. Preke het te doen met verhoudings, huweliksverhoudings, kommunikasie, familie, lewe, sosiaal, polities en ekonomiese dimensies en dissiplines. Ware prediking is inklusief en het te doen met mense se alledaagse sosiale, fisiese, materiële en godsdienstige welstand (Childs 2000:13).

Prediking oor geregtigheid is veronderstel om mense verby hul eie persoonlike verderflikheid en verlossing te neem, en hulle nader te bring 
aan die waarheid van sosiale ongeregtigheid, soos gereflekteer in hul wedersydse vervreemding van mekaar. Met God begin geregtigheid met die uitroep van pyn en gaan dit voort met die werke van genade. Mense se reaksie op die uitdaging van geregtigheid is dikwels egter nie een van genade nie, maar een van raming, van weeg en tel; nie 'n deernisvolle reaksie op pyn nie, maar 'n onbewoë analise van al die struikelblokke vir verandering. Die menslike neiging, as 'n gemeenskap sowel as individue, is om te begin by die opsomming van die probleme wat in die pad staan om hierdie behoeftes aan te spreek (Childs 2000:28).

Om geregtigheid te preek wat nie moralisering is nie, roep mense op om God se geregtigheid in die naam van die evangelie te doen - wat nie net vergewe nie, maar ook 'n nuwe skepping belaai met nuwe moontlikhede. Hierdie belofte is die basis van Christelike hoop. Die hoop van gelowiges se strewe is in hierdie belofte en die nuwe moontlikhede wat dit onder hulle, asook in hulle skep, gevestig. Alhoewel ons in algemene terme kan sê dat alle prediking profeties is, is profetiese prediking in 'n situasie waar 'n gedeelte van die samelewing of gemeenskap ongeregtigheid en uitsluiting ervaar, eiesoortig (Tisdale 2010:4).

Om geregtigheid te preek, alhoewel dit deurdringend in oordeel is, beteken ook om beter te doen as om mense te bestook met wat hulle nie doen nie en wat hulle behoort te doen. Dit beteken om God se woord toe te laat om hul harte te roer vir wat hulle deur die genade van God kan doen. Met ander woorde, prediking wat direk van sonde na redding gaan of van die kruis tot die opstanding sonder om ooit te stop by heiligmaking, mis iets van kritieke belang. Om geregtigheid te preek, wat meer is as moralisering, verkondig God se genade op só 'n manier dat mense telkens bevry word om nuwe mense te wees wie se geloof in God gegrond is (Childs 2000:29).

Die gee van geld vir die gemeente se begroting, kerklike voordele en om te help met noodsaaklike kerklike aktiwiteite, pas by rentmeesterskap. In die breër visie van rentmeesterskap kom die manier hoe Christene geregtigheid binne 'n meer mededeelsame gemeenskap deur politieke, ekonomiese en sosiale maniere uitleef ook aan die orde. Dit beteken 'n direkte deelname in armoede-bestryding en nie net die gee van noodverligting om armoede te bestry nie. Dit is rentmeesterskap as 'n beoefening van geregtigheid in die breedste sin van die woord (Childs 2000:69). 
Dit is belangrik om te verstaan dat armoede nie net ' $n$ voldonge feit van die lewe is nie. Armoede is 'n sluipende en verlagende manier van lewe wat hoop dreineer en die gees van diegene wat daarmee worstel, breek. Armoede neem die vorm aan van 'n onvoldoende dieet waarvan die resultaat elke keer siekte is. Die beste geneesmiddel vir armoede is werk. Dié wat in armoede vasgevang is, vind dit egter moeilik om werk te kry.

Armoede as 'n manier van lewe het ook ander bydraende faktore as dimensies. Die armes moet dikwels in 'n beknopte en gevaarlike publieke huis bly en huur betaal, juis vanweë die feit dat hulle nie 'n maandelikse paaiement op 'n huis kan bekostig nie. As 'n resultaat het die armes nooit die ekonomiese hefvermoë van regverdigheid, belastingaftrekkings en tweede verbande wat beskikbaar is vir diegene wat huiseienaars is nie. Armoede as 'n manier van lewe is nie net beperk tot hulle wat nie werk het en van een of ander publieke bydrae afhanklik is nie. Die meer subtiele en skaam gesig van armoede raak die werkersklas.

Diegene wat wil preek op maniere wat ons aandag vestig op die probleem van armoede en ekonomiese ongelykheid moet verstaan dat die meeste van hierdie probleme opgelos kán word, onder andere deur kreatiewe en moedige veranderinge in sommige van ons land se openbare beleide. Predikers word dus opgeroep in hul prediking om hierdie openbare beleide aan te spreek en bloot te lê. Predikers kan help om 'n nasionale konsensus teenoor sulke beleide te bou. Die probleem wat geassosieer word met armoede en ekonomiese ongelykheid het 'n definitiewe effek op mense en ook op die wêreld. Dit is baie makliker vir die prediker om hierdie sake te ignoreer en uitsluitlik te fokus op veilige onderwerpe soos liturgiese seisoene en denominatiewe punte van belang. Die feit is egter dat God predikers oproep om op te staan en te praat oor hierdie belangrike sake wat 'n impak op lidmate se lewe het en ook 'n impak op die kwaliteit van lewe van miljoene ander oor die hele Suid-Afrika en die wêreld het (McMickle 2007:12).

Baie politieke leiers se beloftes is leë beloftes omdat die kerk hulle nie verantwoordelik hou vir hierdie beloftes nie. Die kerk is dus gevlei deur hierdie persone se teenwoordigheid en behandel hulle soos beroemdes en nie soos publieke dienaars wat in posisies van mag sit om geregtigheid deur regte sisteme aan almal te voorsien nie. Die kerk se opdrag is om 
juis deur die prediking ook hierdie mense bewus te maak wat hulle moet doen om hul ampte te vervul. Die kerk het deur die prediking die mag om verandering ook in hierdie sistemiese verband te bring. Die kerk kan deur die prediking die stem wees wat leiers verantwoordelik hou vir hul beloftes. Die werkende middelklas asook die armes se stem word so gehoor.

Om te preek oor sake van geregtigheid gee predikers die ideale geleentheid om die realiteite van die slegte nuus onder mense se aandag te bring. In plaas daarvan om lidmate op tydelike en sporadiese skuldgevoelsessies te neem in die vorm van preke, beteken geloofwaardige en effektiewe prediking oor geregtigheid 'n deeglike analise van die huidige slegte nuus wat mense se huidige bestaan raak, maar ook die verkondiging van die goeie nuus van God se volgehoue dekonstruksie van dominerende magte (Brown 2003:19).

Sodanige prediking het trouens die vervanging van hierdie magte met gemeenskappe wat omgee en geregtigheid wat vir almal bedoel is op die oog. Sulke prediking transformeer die prediker en die hoorders se lewe tot volhoubare beliggaming van geregtigheid en geloofwaardige aksie (Childs 2003:35).

Tog is dit moeilik om vandag oor geregtigheid in ons samelewing te preek. Ons samelewing het so gepolitiseer geword dat mense baie keer woorde soos geregtigheid, lewe, die armes en selfs passie hoor as kodewoorde vir een of ander politieke beweging. Daar is 'n baie dun lyn tussen prediking oor geregtigheid en moralisme. Prediking oor geregtigheid kan ook die gevaarlike pad loop waar ideologiese korrektheid karakter-ontwikkeling vervang. Mense kan verkeerdelik verstaan dat om aan die regte kant van sosiale kwessies te wees, nie noodwendig beteken om 'n transformasie van hart en gedagtes te ondergaan nie (Ortberg 2010:52).

Vir sommige predikers is dit baie makliker om met hul gemeentes te praat oor liefdadigheid as oor geregtigheid. Liefdadigheid bedreig glad nie die status quo waarby 'n groot aantal lidmate voordeel kan vind nie, terwyl geregtigheid aan die ander kant direk kan lei tot politieke omstredenheid (Coffin 2003:49-53).

\subsection{Etiese prediking kan die taal van hoop verwoord}

Prediking kan ook verstaan word as 'n bemagtiging tot hoop. Die doel daarvan om hoop te preek, is om luisteraars te skep wat op hul beurt hoopvol 
sal praat. Doelbewus en arbeidsaam sal die prediking die luisteraars moet bring tot 'n posisie waar hulle hul eie hoop kan uitspreek en waar hulle in hul eie stem kan praat. Om hoop te preek, is om jou luisteraars te bemagtig om verantwoordelike, selfvoorsienende getuies te wees van wat hulle gesien, gehoor en gelees het. Prediking van hoop beteken om mense so te bemagtig dat hulle self niks anders kan wees as predikers van hoop nie (Hermelink 2007:42-43).

Betroubare en ware prediking benodig 'n perspektief op hoop wat gewortel is in die realiteit. Selfs in tye waar daar 'n gebrek aan perspektief is, kan 'n homiletiese manier gevind word om hoop te preek, aangesien hoop die mees essensiële deel van prediking en geloof vorm. As hoop iets is wat gedeel moet word, kan prediking gedefinieer word as 'n manier om hoop te deel. As prediking beteken om te deel, dan is dit belangrik dat prediking regte ervarings deel en dat prediking 'n deel vorm van 'n voortgaande gesprek, soos tans gepropageer in sommige homiletiese konsepte. Gesprekvoerende konsepte van prediking moet verbind word met die teologie van hoop in Jesus Christus.

Prediking wat hoop gee fokus op die transformerende krag van die koninkryk van God. Dit beteken dat homiletiese teorie en navorsing fokus op die uitkoms van die predikingsproses en die ontvangs van prediking. Die taal van hoop is sensitief en oop vir ou en nuwe simbole van hoop. Die taal van hoop het 'n dimensie van die "alreeds" en die "nog nie" in die verkondiging. Prediking van hoop bevat 'n fundamentele appèl om in God se transformerende koninkryk betrokke te raak, maar ook 'n profetiese dimensie om valse hoop te identifiseer (Stark 2007:107-109).

Volgens Pieterse bestaan daar nie getoetste kennis oor wat predikers in Suid-Afrika in hul preke aan arm mense of oor armoede verkondig nie (2009: 135). Die vermoede bestaan dat daar 'n navorsingsleemte in die veld bestaan wat betrekking het op wat predikers in hul prediking sê oor armoede en die manier waarop hulle hulle prediking rig waar arm mense 'n groot deel van die hoorders uitmakk. In 2013 is daar empiriese werk gedoen vir 'n doktorsgraad in teologie ${ }^{4}$ die eerste in die soort binne die

4 Titel van navorsing: "Die rol van prediking in die bevordering van gemeenskapsontwikkeling: 
Verenigende Gereformeerde Kerk. Vooraf is met predikers gekonsulteer om volledige manuskripte aangaande prediking oor armoede te bekom. Dit was nie preke wat op die spesifieke Sondag tydens die navorser en veldwerkers se besoek aan gemeentes gepreek nie. Al die preke is verkry deur 'n oorspronklike manuskrip van die verskillende leraars binne 'n ring van die VGKSA te ontvang. Die preke beskik egter nie oor 'n spesifieke datum en tyd wanneer dit gepreek is nie, maar dit was wel in 'n postapartheidtyd gepreek.

Daar is gepoog om op 'n induktiewe wyse met behulp van preekanalises van die preke self oor hierdie saak ondersoek in te stel. Die invalshoek waarmee die terrein van ondersoek benader word, was om induktief vas te stel wat predikers oor armoede preek en wat hul boodskap was oor hoe die gemeente in die konteks van armoede behoort op te tree. Al hierdie inligting is gebruik om vas te stel wat die lidmate se persepsies aangaande die kerk se betrokkenheid in armoedebestryding is. Die inligting het ook gehelp om te toets hoe sekere tipes prediking mense beïnvloed het of watter tipes prediking deur lidmate ondersteun is. Daar is ook gekyk of daar werklik volgens lidmate oor die betrokkenheid in die bestryding van armoede gepreek is. Vir die data-analise deur die navorsing is 'n aantal preke geanaliseer ten einde vas te stel tot watter mate dit as etiese prediking in 'n konteks van armoede gefunksioneer het. Hierdie preke is geensins verander nie, maar is net soos dit deur die predikers verskaf is, gebruik. Slegs geskrewe preke is geanaliseer - geskrewe preke wat wel op 'n spesifieke tyd in 'n gemeente van die VGK binne 'n ring gepreek is.

Dit was belangrik om die gepaste model van inhoudsanalise te vind vir die spesifieke vraagstelling en benadering tot die preek-analise waarmee besig was. In die navorsing is daar van die internasionaal erkende Heidelbergmetode ${ }^{5}$ gebruik gemaak wat in die tagtigerjare van die vorige

'n kontekstueel-teologiese besinning." Proefskrif ingelewer vir 'n doktorsgraad in teologie aan die Universiteit Stellenbosch. Desember 2013.

5 Enersyds word die oppervlakstruktuur van die preekteks bepaal, en andersyds die dieptestruktuur daarvan. So kom die grondmotiewe van die prediker aan die lig. Die preke in hierdie analises is linguisties en teologies geïnterpreteer, deur by elke preek die wisselwerking tussen die oppervlak- en dieptestrukture, tussen eksplisiete en implisiete taal, noukeurig na te gaan. Die Heidelbergmetode is 'n intratekstuele metode wat deur 'n "close reading" van die preekteks deurdring tot die grondstrukture van die preek en ook tot die teologie wat die prediker in sy/haar preek verwoord. 
eeu deur die Switserse homileet Rudolf Bohren en die Duitse skrywer Gerd Debus ontwikkel is.

Al die uitgangspunte van hierdie metode is ondersoek, naamlik dat elke preek in mindere of meerdere mate die prediker se teologie of gebrek daaraan verwoord. Dikwels word die eintlike teologie wat die bepalende hermeneutiek dra, in die skynbaar onbelangrike taalkonstruksies van 'n preekteks verberg. Die metode bestaan uit 'n aantal analitiese sowel as sintetiese stappe. Hierdie metode van analise is niks anders nie as 'n gekonsentreerde lees en herlees van die preekteks, ten einde so na as moontlik te kom by dit wat werklik gesê word. Die metode bied dus 'n interpretasie van die teks, 'n hipotese wat vra om getoets te word (Cilliers 1996:238).

In kort het uit die ontleding van die verskillende preke geblyk dat daar soms pertinent gesê is dat indien lidmate geestelik reg is, hulle deur die regte houding en ingesteldheid die wêreld kan verander. Lidmate self kan verandering bring, maar ook verandering buite die kerk. Die preke het nie een direk oor armoede binne die gemeente self gehandel nie. Verandering deur lidmate kan buite gemeente verband gedoen word. Dit was baie duidelik dat die arm mense na wie hierdie preke verwys het, nie binne die VGK was nie. Tog is die VGK 'n kerk vir die armes en ook van die armes. In hierdie preke word die tema van armoede ook nie direk genoem nie, die woord armoede word nie meer as tien keer in al vier preke genoem nie. Dit alles terwyl armoede 'n brandende onderwerp in die kerk en selfs in alle regerings onderwerpe is.

Die omgang met die Bybelteks was ook skokkend. Morele lesse of stories was die middelpunt van die preek en waar rondom die preek gebou is. Die Bybelteks is gebruik as 'n slot of bevestiging van hierdie morele les of storie.

In al vier preke was daar net twee preke wat eintlik werklik eksegese van die teks gedoen het. Die mens was in al hierdie preke die sentrale punt deur wie se regte of selfs positiewe handeling alles kan verander. Mense moet net die voorwaardes van God nakom sodat die wil van God geaktiveer kan word. Mense kan deur hierdie voorwaardes die beloftes van die tekste waar makk. Dit was asof God sekondêr staan en die mens primêr is ten opsigte van die handeling wat verandering kan bring. 
Mense is in hierdie preke gevra om reg teenoor hul naastes op te tree sodat hulle ordentlike Christene in daardie samelewing en ook in die kerk kan word, mense met 'n basiese passie vir diegene daarbuite. Dit was asof hierdie preke simplistiese oplossings bied - indien lidmaat A doen sal lidmaat B volg. Die aktuele saak van armoede word nie met konkrete inhoud gepak of positief gevul met die belofte van die evangelie nie. Dit is in al die preke in hierdie studie baie duidelik dat daar by die natuurlike, doodgewone en alledaagse leefwêreld van die hoorders verby gepreek is. Die preke raak nie eintlik die hoofbestanddele van lidmate se alledaagse werklikheid nie. Dit is asof lidmate net die opdrag ontvang om 'n sendeling te wees. In die preek het die prediker ook die punte wat op die agenda van die regering hoort, gesit. Dit wat nie met die eise van die Woord van God strook nie, is nie bekendgemaak nie.

Die VGK is 'n kerk waarvan die oorgrote meerderheid van die lidmate elke dag werklik met armoede as 'n wesenlike probleem worstel. Armoede is 'n deel van die VGK se alledaagse uitdagings. Dit is dus 'n kerk nie net vir die armes nie maar ook 'n kerk van die armes. Indien dit dus 'n kerk van die armes is, moet daar tog werklik oor armoede gepreek word en hoe God volgens die Belydenis van Belhar op 'n besondere wyse die God van die verontregte is. Dit sou ideaal gewees het om preke op te spoor wat oor armoede handel en nie oor optrede teenoor mense in armoede nie. Die ondersoek wou egter nie sê dat daar op hierdie manier in die hele SuidAfrika of in die VGK oor die afgelope tydperk na bevryding oor armoede gepreek is nie. Maar wel: So is daar ook gepreek. Daar het natuurlik ander stemme opgeklink, stemme wat die situasie oor armoede anders verwoord het. Daar is ook preke, miskien die meerderheid, wat geen woord oor die situasie rep nie.

Die krisis in ons prediking sentreer vir die huidige, na my mening, hoofsaaklik rondom die inhoud van ons prediking. Dit was duidelik uit die inhoud van die preke wat ontleed is en mense se verstaan daarvan, asook in die verleentheid van ons predikers om in 'n veranderde situasie in ons gemeenskappe nog die Woord van God op só 'n manier te verkondig dat dit werklik tot mense spreek, dat dit inspireer en ook aanspreek.

Cilliers (2015:5) stel dit so mooi: 
Preaching has become more tentative than before, no longer emanating from the certainty of a fixed and stable truth. On the other hand, preachers tend to be very pragmatic in their approach, desperately trying not to rock the (sinking) boat too much. Preaching has to an extent taken on the mode of maintenance, rather than being an expression of innovative theology.

En tog uit die navorsing en volgens Campbell, Cilliers (2015: 6) en Cilliers $(2012: 55)^{6}$ is dit asof die verenigde, profetiese stem van die kerk in SuidAfrika afwesig is. Dit is asof die kerk sy energie om teen sosiale euwels soos armoede, korrupsie, misdaad en stigma te stry verloor het. Dit blyk dat die huidige ervaring deur prediking een van onsekerheid aan die een kant en introversie aan die anderkant oproep.

Die huidige stilte deur "n gedeelte van die kerk van Suid Afrika kan volgens Cilliers (2015:3) toegeskryf word aan ten minste huiwerigheid om teen sosiale euwels te spreek. Die etiese stem van kerk het tot 'n groot mate stil geword en is byna geneutraliseer.

Prediking volgens Allan (2015:129-152)

... should be taken out of its admirably formulated and avidly defended constructs, to be reborn out of the kairos of the marginalised, out of the crises of those on the edges, out of the cries of those on the borders of life and society ...

Die rol van die prediking as meningsvormer moet egter nie oorskat, of onderskat word nie, veral as dit handel oor die legitimering en bestendiging van bestaande godsdienstige en sosiale profiele. Die prediking is dikwels slegs 'n spieëlbeeld van die gemeenskap wat dit bedien (Muller 1989:43-44).

Die profetiese verantwoordelikheid wat op die prediker rus, kan alleenlik vervul word wanneer die prediker praat oor die behoeftes van die gemeentelede. Predikers kan egter nie net tot mense se behoeftes preek in die lig van wat aan hulle bekend is deur hul kennis van die gemeente nie, maar is as predikers ook onder die verpligting om gemeentelede aan te moedig om korrupsie, onvoldoende behuising en ongeregtigheid op arbeidsvlak teen te staan. Predikers as profete is vandag genoodsaak as

6 Preaching Fools, Campbell C en Cilliers J (2012:55) 
etiese en sosiale verhoudingsbouers om die voortou neem as dit kom by die verbetering van gemeenskappe (Perry 1973:104).

In die lig van die voorafgaande stel ek as algemene vertrekpunt voor dat daar kennis geneem word van bepaalde teologiese en hermeneutieshomiletiese oorsake agter die stilswye rondom prediking in situasies van armoede, asook agter die gebrekkige pogings in hierdie verband. Naas hierdie teologiese probleme, en as uitvloeisel daarvan, is daar ook 'n grondliggende hermeuties-homiletiese probleem, naamlik die gebrekkige of foutiewe interpretasie van die sosio-politieke werklikheid van armoede. Dit kom basies daarop neer dat die prediker nie vertroud is met die sosiale gemeenskap waarin hy of sy die boodskap kommunikeer, en waarbinne hy of sy die boodskap moet interpreteer nie. Predikers is dikwels onbekend met die verwysingsraamwerke van hul gehoor, hul waarders, hul lewensuitkyk en hul behoeftes. Daarom kan predikers ook nie die prediking as informasiemedium op 'n hermeneuties-verantwoorde wyse benut nie.

Vervolgens, drie slotopmerkings met betrekking tot prediking as middel van verandering.

Eerstens: Die tyd waarin ons leef vra 'n nuwe en onvoorwaardelike gehoorsaamheid aan die Woord van God. Predikers kan slegs hul roeping uitleef as hulle tot 'n eerlike selfondersoek van hulle roeping voor God en met nuwe visie en roepingsbewustheid God se Woord laat spreek in die hoorders se konkrete lewensituasies. Wanneer die werklikheid indruis teen die beginsels van die Woord van God, is dit die prediker se verantwoordelikheid om nog steeds God se Woord helder, duidelik en konkreet hieroor laat weerklink. God se Woord is soewerein en wil juis in die skynbaar onveranderbare sosiale werklikheid van armoede deurbreek. Wanneer predikers God se Woord laat spreek oor armoede is hulle ten diepste besig om God se reg en geregtigheid te proklameer. Hierin lê die diepste grond vir enige verandering.

Tweedens: Dit is van kardinale belang dat predikers toesien dat hulle deeglik op hoogte is en kennis dra van die sosiale werklikheid en omstandighede van die gemeentelede as hoorders van hulle preke. Predikers wat hul lidmate liefhet nie anders kan as om verantwoordelikheid te aanvaar vir diegene vir wie hulle preek nie. Iemand wat liefhet, kan hom of haar nie van ander onttrek nie. Ons preke kan die beste inhoude bevat, maar inhoud is nie 
alles nie. Predikers moet hulle lidmate ken, hulle moet 'n grondhouding van liefde hê vir hulle lidmate. Predikers kan nie net alleen kennis dra van sy of haar hoorders se verwysingsraamwerk, lewensuitkyk en omstandighede nie, maar grondige kennis oor die sosiale aangeleenthede waaroor hulle uitsprake en oordele waag, is ook noodsaaklik. Die enigste manier om dit te doen is om 'n persoonlike openheid teenoor lidmate te behou, 'n solidariteit met mense, veral ook arm mense te betoon, en om mense werklik in hulle omstandighede te ontmoet ( $\mathrm{Nel}$ 2001:73).

Derdens: Dit is eers as predikers self eers praktiseer wat hulle aan hul gemeente voorstel; self eers beliggaam waartoe hulle ander oproep, dat dit ware prediking is. $\mathrm{Na}$ elke preek wat gehandel het oor armoede kan daar 'n geleentheid geskep word waarin die gemeentelede kans kry om hierdie beginsel toe te pas en uit te leef, sodat hulle hulself daarin kan inoefen en paraat kan wees as hulle dit in hul eie unieke lewensituasie moet toepas. In hierdie inoefening is die prediker egter die voorganger. Woorde wek, maar dade trek. Die woorde en die gedagtes wat in die prediker se hart leef word só in 'n besondere sin simbolies van aard: toekomsklanke wat nou reeds in die gemeente gesien en gehoor word. Dit is seker die allerbelangrikste eis vir die prediking, want die boodskap van die Christelike hoop is 'n boodskap wat oproep tot verantwoordelikheid, tot 'n nuwe lewenswyse, tot 'n nuwe kwaliteit van lewe - tot hoop.

Die tyd waarin ons leef, roep hierom uit.

\section{Bibliografie}

Allan, R 2015. Preaching as Spark for Discovery in Theology. Homiletical Theology. Preaching as Doing Theology. The promise of Homoletical Theology Volume 1. Editor David Schnasa Jacobsen. Eugene, Oregon: Cascade Books.

Boesak, A 1979. Die Vinger van God. Preke oor geloof en die Politiek. Johannesburg: Ravan Press.

Brown, D 2003. Faith plus persistance pays off. Luke 18:1-8 In Resner, A Jr. (red). Just Preaching. Prophetic Voices for Economic Justice. St Louis: Familiy Promise, Charlice Press. 
Burrows, S 2013. Die rol van prediking in die bevordering van gemeenskapsontwikkeling: 'n kontekstueel-teologiese besinning. Proefskrif ingelewer vir die DTh graad in teologie aan die Universiteit Stellenbosch Desember 2013.

Buttrick, D 1987. Homeletic: Moves and Structures. Philadelphia: Fortress Press.

Campbell, C 2002. The Word before the Powers: an Ethic of Preaching. Louisville: Westminster John Knox Press.

Campbell, C \& Cilliers, J 2012. Preaching Fools. The Gospel as a Rhetoric of Folly. Waco, Texas: Baylor University Press.

Childs, J. 2000. Preaching Justice. The Ethical Vocation of Word and Sacrament Ministry. Harrisbrook: Trinity Press International.

Childs, J. 2003. Enabling Grace. In Resner, A Jr. (red). Just Preaching. Prophetic Voices for Economic Justice. St Louis: Familiy Promise, Chalice Press.

Cilliers, J 1996. Die uitwissing van God op die kansel. Ontstellende bevindinge oor Sui-Afrikaanse prediking. Kaapstad: Galvin \& Sales.

Cilliers, J 2000. Die genade van gehoorsaamheid. Hoe evangelies is die etiese preke wat ons in Suid-Afrika hoor? Wes-Kaap: NBD.

Cilliers, J 2013. Nederduitse Prophetic preaching in South Africa: exploring some spaces of tension. Gereformeerde Tydskrif. Deel 54, Nommer $1 \& 2$.

Cilliers, J. 2015. Between separation and celebration: Perspectives on the ethical-political preaching of Desmond Tutu. Stellenbosch Teologiese Joernaal. Volume 1, Nommer 1.

Cilliers, J 2015. Where have all the prophets gone? Perspectives on political preaching. Stellenbosch Teologiese Joernaal. Volume 1, Nommer 2.

Coffin, W 2003. The Politics of Compassion. In A. Jr. (red). Just Preaching. Prophetic Voices for Economic Justice. Resner, St Louis: Familiy Promise, Charlice Press. 
Crossin, J 1998. Walking in Virtue: moral decisions and spiritual growth in daily life. Mahwah: Paulist Press.

Feltmann, R 1996. "Preaching for Transformation.” A doctoral dissertation submitted to the faculties of the schools of the Atlanta Theological Association in partial fulfillment of the requirements of the degree of Doctor of Ministry at Columbia Theological Seminary.

Gous, N 2017. SA most unequal country in world: Poverty shows Apartheid's enduring legacy. Times Live, 4 April 2018. [Online]. Available: https://www.timeslive.co.za/news/south-africa/2018-04-04-povertyshows-how-apartheid-legacy-endures-in-south-africa/ [Accessed 8 October 2018].

Hauwerwas, S 1977. Truthfulness and Tragedy: further investigations in Christian Ethics. Notre Dame: University of Notre Dame Press.

Hendriks, J 1998. "Gemeenskapsontwikkeling as missionêre taak van die kerk." Werkstuk ingelewer ter gedeeltelike voldoening aan die vereistes vir die graad Baccalareus Divinitatis. Stellenbosch: Universiteit van Stellenbosch.

Hermelink, J 2007. The Theological understanding of preaching hope. In Cas, J, Lucy, L, Cilliers, J (reds). Preaching as a language of hope. Homililetica Societas. Studia Homiletica 6. Pretoria: Protea Book House.

Kim, C 1999. "The significance of prophetic preaching: the implications of Isaiah's message for contempory preaching." Thesis (D.Th.), University of Stellenbosch.

Mcmickle, M 2007. Preaching on Issues of Poverty and Justice. In The Clergy Journal 83(6), 11-13.

Miller, D 2003. The Prophet's Sons and Daughters. In Resner, A. Jr. (red). Just Preaching. Prophetic Voices for Economic Justice. St Louis: Familiy Promise, Charlice Press.

Mitchell, H 1990. Celebration \& Expierence in Preaching. Nashville: Abingdon Press. 
Mugambi, J 2003. Christian Theology and Social Reconstruction. Theology of Reconstruction Series. Nairobi: Acton Publishers.

Muller, B. 1989. "Ondersoek na tendense in Afrikaanse godsdienstige uitsendings van die SAUK en na hermeneutiese en homiletiese beginsels wat ten grondslag daarvan lê.” Universiteit Stellenbosch.

Nel, M 2001. Ek is die Verskil. Die invloed van persoonlikheid in die prediking. Bloemfontein: CLF-Uitgewers.

Ortberg, J 2010. Preaching like a Prophet. We dare not be silent about injustices, if only we can see them as God does. In Leadership Journal.

Perry, L 1973. Biblical Preaching for Today's World. Includes sermon variation, life situation preaching, doctrinal communication. Chicago: Moody Press.

Pieterse, H 2001. "Prediking in 'n konteks van armoede." Pretoria: Universiteit van Suid-Afrika.

Pieterse, H 2013. Prophetic preaching in the contemporary context of South Africa. Skriflig. Volume 47, Nommer 1.

Stark, C. 2007. "Flickering Hope After 40 Years": A Rereading of Moltmann's Theology of Hope for Today's Preaching." In Cas, J, Lucy, L. \& Cilliers, J (reds). Preaching as a Language of hope. Homililetica Societas. Studia Homiletica 6. Pretoria: Protea Book House.

Swart, I 2004b. Community-centred congregational ministry in South Africa: a plea for renewal. NGTT Supplementum 2004, Deel 45, Nommer 2.

Statistics South Africa. 2017. Poverty Trends in South Africa: An examination of absolute poverty between $2006 \& 2015.22$ August 2017. [Online]. Available: http://www.statssa.gov.za/?p=10341 [Accessed: 8 October 2018].

Tisdale, L 2010. Prophetic preaching: A pastoral approach. Louisville: Westminster John Knox Press. 